species from the Bradford Clay. One is an Antedon, the oldest known, with no special characters; the other is an Actinometra, with a centrodorsal essentially like those of species now living in shallow water in the Philippines and Malay Archipelago. The oldest known Comatula, an Actinometra from the Bath Oolite, has similar relations.

\title{
CORRESPOINDEINCE.
}

PETROLOGICAL NOMENCLATURE.

SiR,--Mr. S. Allport's excellent paper on "The Rocks of Brazil Wood" (Vol. VI. p. 481) incidentally suggests a general question to which, at the present time, it may be worth while calling attention. In this particular case, however, I am not persuaded that the name "micaceous schist" is any better than "gneiss" for the Brazil Wood rock. In writing of it I left the name gneiss, which had already been applied to it, unchanged, because I was not able to suggest a better. The foliation is so slight, as Mr. Allport observes, that the name schist (which calls attention to that property) does not seem appropriate; and we are not unfamiliar with rocks, to which we at present extend the term gneiss, which exhibit that phenomenon very imperfectly. A more serious objection is, as $\mathrm{Mr}$. Allport remarks, that there is generally no felspar visible. The microscope, however, shows a third constituent, and the analysis ${ }^{1}$ suggests the presence of an aluminous mineral. In this, if we assume that all the magnesia is present in a magnesia-mica, and all the soda in a soda-mica, we find (using rough approximations founded on some of the analyses given in Dana's Mineralogy) that to form these micas we require for the one about $\mathrm{SiO}_{2}=4 \cdot 6$ $\mathrm{Al}_{2} \mathrm{O}_{3}=2 \cdot 2 \mathrm{FeO}=2, \mathrm{~K}_{2} \mathrm{O}=\cdot 8$; and for the other about $\mathrm{SiO}_{2}=7 \cdot 0$ $\mathrm{Al}_{9} \mathrm{O}_{3}=4 \cdot 2 \mathrm{FeO}=\cdot 3$. Thus we have still left unemployed about $\mathrm{SiO}_{2}=42 \cdot 4 \quad \mathrm{Al}_{2} \mathrm{O}_{3}=15 \cdot 47, \quad \mathrm{~K}_{2} \mathrm{O}=2 \cdot 8$; this (with the $\mathrm{H}_{2} \mathrm{O}$ ) seems to indicate some zeolite, which may hare resulted from the destruction of a felspar. The rock then, though not strictly speaking a gneiss at present, may have been a kind of gneiss; though, under the circumstances, it is also possible that the felspathic constituent passed at once from the state of mud to its present condition.

This rock, then, is an example of a class of difficulties unpleasantly familiar to every petrologist. With an abundance of synonyms in some cases, our nomenclature is very defective in others. Thus, following the lead of the older geologists, it does not recognize clearly enough that the metamorphic rocks are not so much a third class independent of the other two ${ }^{2}$ and of equal value, but that every rock, whether igneous or stratified, may have its metamorphic representa-

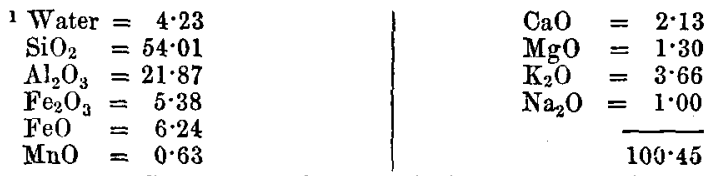

S.G. $=2.85$ (Q.J.G.S. Vol. xxxiv. p. 224).

2 Using for the occasion the old division into igneous and stratified. 
tive. Again, in the case of metamorphic sedimentary rocks, we find one group which exhibits foliation very distinctly, another which does not. Now there is no name, so far as I am aware, for the rock in the latter group, which is the equivalent of gneiss in the former. ${ }^{1}$ Again, unless we accept such a term as Hornblende rock (which I do not like), we have no name for the equivalent of Hornblende schist; and the same is true of other schists. Names like Hälleflinta, Hornstone, Lydian stone or Lydite, Porcellanite, want definitely fixing or deliberately leaving as indefinite-we have, in fact, no satisfactory nomenclature for the extensive group of compact felstone-like or flinty altered rocks.

In the case of the igneous rocks, also, several points require settlement. The limits of the terms Quartz-felsite (or Quartzporphyry, a name I much dislike), Quartz-trachyte, and Rhyolite require fixing. We have to consider whether we ought or ought not to separate the microcrystalline from the cryptocrystalline Quartzfelsites, and then to decide what are the essential characteristics of a Quartz-trachyte, what are the limits of the name Rhyolite, and what view is to be taken of devitrified rhyolites. At present, as it seems to me, there is no line drawn between some Quartz-felsites and Quartz-trachytes, other than geologic age, which I for one do not think a safe basis for classification. Again, assuming that we take crystalline condition as the basis of subdivision in our groups, separated at first by mineral (or chemical) composition, the meaning of the term basalt requires fixing, and the groups of the nepheline and the leucite rocks are very unsettled. The same may be said of the "mica-traps," peridotites, and others, which, did space allow, it would be easy to name; but the above remarks may suffice to call attention to a real difficulty, which I imagine is widely felt by students of petrology.

St. Johy's Coliege, CAMB . Ing p, November $20 t h, 1879$.

T. G. Bonney.

\section{DR. WAAGEN'S VIEWS ON THE GEOLOGY OF THE SALT RANGE IN INDIA.}

Sin,-With reference to part of my letter in your September Number bearing upon Dr. Waagen's suppression of the Silurian group in the Indian Salt Range, I have since learned he has made the important admission : that for a time Stoliczka and himself were of opinion the fossils which I found in the Obolus group belonged to the Silurian period, and even now [May, 1879] he was " not prepared to maintain with certainty that that opinion was incorrect." " Notwithstanding this, in the case in point, ${ }^{3}$ Dr. Waagen has not hesitated to condemn the classification adopted by me, although he elsewhere confessed himself uncertain of its being in error.

\section{A. B. WYNNE.}

I I have proposed that of granitoidite, Q. J. G. S. vol. xxxv. p. 322 .

2 Neues Jahrbuch für Mineralogie, etc., 1879, "Ueber einige strittigen Punkte in der Geologie Indiens. Dr. W. Waagen. Wien, 1 Mai, 1879."'

3 Pal. Ind. Series xiii. Salt Range Fossils. 